This is an Accepted Manuscript of an article published by Taylor \& Francis in Journal of Sustainable Tourism on 16/09/2019, available online:

http://www.tandfonline.com/10.1080/09669582.2019.1650054

\title{
Overtourism and tourism degrowth: a social movements perspective
}

\author{
Claudio Milano ${ }^{\mathrm{a}}$, Marina Novelli ${ }^{\mathrm{b}}$ and Joseph M. Cheer ${ }^{\mathrm{c}}$ \\ a Ostelea School of Hospitality and Tourism, University of Lleida, Barcelona, Spain \\ b School of Sport and Service Management, University of Brighton, Eastbourne, UK \\ ${ }^{\mathrm{c}}$ Wakayama University, Japan
}

\begin{abstract}
Overtourism is a contemporary phenomenon, rapidly evolving and underlined by what is evidently excessive visitation to tourist destinations. This is obvious in the seemingly uncontrolled and unplanned occurrence of urban overtourism in popular destinations and arguably a consequence of unregulated capital accumulation and growth strategies heavily associated with selling cities as tourism commodities. The vested interests of social movements has converged into growing protests against overtourism and associated degrowth campaigns have emerged out of this activism that calls for alternative governance and management measures that eschew touristic monoculture and simplistic economic growthoriented models. Accordingly, we explore the evolution of the tourism degrowth discourse among social movement activists in Barcelona, and in particular, where this is related to claims associated with overtourism and the extent to which this might be influencing a paradigm shift from 'tourism growth' to 'tourism degrowth'. Methodologically, we draw from an overarching framework that leverages long-term ethnographic research in Barcelona. Here, we employ Rapid Situation Analysis (RSA) including in-depth semi-structured interviews, participant observations, informal conversations and retrospective evaluation of field diary entries.
\end{abstract}

\section{Introduction}

During the 1950s and 1960s, embedded liberalism policies delivered high rates of economic growth to only a handful of national economies, thus raising concerns regarding equality and inequality (Harvey, 2007). This period was marked by a firm belief that growth was synonymous with development and this train of thought has been employed widely since the 1950s as an economic paradigm associated with the push for more prosperous conditions in non-industrialized economies (Escobar, 2014). Indeed, that growth does not necessarily equate to sustainable development is a well-established truism (Hall, 2010; Novelli, 2015), with some critics addressing 'degrowth' as the antithesis of growth itself (Latouche, 2014; 2009). Over the last decade, there has been a boom in the sheer numbers of international conferences, peer-reviewed publications and reports on degrowth and particularly, sustainable degrowth (Martınez-Alier, Pascual, Vivien, \& Zaccai, 2010; Schneider, MartinezAlier, \& Kallis, 2011). 
Evidently, there is increasing grassroots activism and the development of research networks concerning degrowth such as the Research \& Degrowth (R\&D) Association (Kallis, Demaria, \& D’Alisa, 2014). The ensuing degrowth debate has overlapped with the leap from modernity to postmodernity and has coincided with the shift from embedded liberalism to neoliberalism (Harvey, 1990). Together with the 1970's neoliberal city boom, urban spaces have witnessed intensive land improvement and real estate speculation, higher population densities and increased levels of economic activity (Molotch, 1976).

Tourism is considered the fastest growing and most widespread industry worldwide (UNWTO, 2018) and has arguably made a considerable contribution to the proliferation and functioning of the capitalist world system (Fletcher, 2011). It is within this milieu that tourism and the degrowth agenda intersects and underlined by the spread of global mass tourism that has inevitably attracted mounting criticism, particularly regarding the controversial relationship between tourism, growth and development, and the extent to which it builds resilience and adaptive capacities (Cheer, Milano, \& Novelli, 2019; Cheer \& Lew, 2018; Lew \& Cheer, 2018).

The heightened interest in selling cities as authentic commodities for tourism purposes has proliferated to become a fast-evolving and alternative form of capital accumulation (Harvey, 2007). Concurrently, urban overtourism emerged, with visitation growth leading to overcrowding in areas where residents suffer the consequences of temporary and seasonal tourism peaks, enforcing permanent changes to their lifestyles, and impinging access to amenities and the realisation of optimum well-being (Milano, Cheer, \& Novelli, 2019).

Notwithstanding, the contemporary debate on the effects of over-visitation and overcrowding of tourism destinations, general concerns and related theoretical discourses addressing the problems of excessive tourism growth are not new and were flagged more than forty years ago by Turner and Ash (1975) and Doxey (1975), followed by Butler (1980), UNWTO (1983), O’Reilly (1986), Boissevain (1996) and more recently by Colomb and Novy (2016), Koens, Postma, and Papp (2018) and Milano and Mansilla (2018). In more recent times, the debate has shifted toward overtourism and the emergence of the degrowth discourse in tourism studies (Andriotis, 2018; Hall, 2009).

This article offers a critical examination of the controversial debates linking overtourism, social movement activism and degrowth in the city of Barcelona. While the city has experienced exponential increases in visitor arrivals, and overall economic activity, the tourism degrowth discourse has emerged, underlined by the political agenda of social movements. Over the last decade, Barcelona has become emblematic of tourism growth that has come to be resisted by social movements. By assessing the activities of grassroots movements such as the ABTS (Assemblea de Barris per un Turisme Sostenible - Assembly of Neighbourhoods for Sustainable Tourism) and SET (Red de ciudades del Sur de Europa ante la Turistizacion - Network of Southern European Cities against Touristification), we emphasise how social movements align with the degrowth discourse.

The Barcelona Strategic Tourism Plan for 2020' that estimates 30 million visitors annually, of which half are overnight visitors, the remainder being day-trippers (Barcelona City Council, 2016) underlines the ABTS and SET Network's tourism degrowth campaigns against what they consider to be unsustainable and socially disruptive growth. The ABTS and SET Network propose an alternative model of governance, agitating for shifts away from a touristic monoculture and simplistic economic growth-oriented approach, to one that 
encourages tourism degrowth characterised by steady-state tourism theory and rooted in protection of local resident quality of life and wellbeing (Hall, 2009). More recently, the focus of social movements has shifted to directly campaigning against overtourism, with ABTS the forerunner. Although such activism is by no means unprecedented with various Barcelona neighbourhoods having experienced protests against overtourism, hotel development projects and HUT (housing for touristic use) (Blanco-Romero, Blazquez-Salom, \& Canoves, 2018; Gant, 2016; Mansilla, 2018; Milano, 2017b; 2018; Russo \& Scarnato, 2018).

Since ABTS was established in November 2015, as a grassroots organisation initially formed by thirty-five Barcelona-based social movements, associations and entities, it has shaped the tourism degrowth agenda and has become central to public events, stakeholder meetings, debates and campaigns focusing on city rights, cost of living, housing affordability, reduction in the numbers of tourists arriving in the city and incoming flights, and other practices that heighten the proliferation of unmanageable and unsustainable tourism flows. Based on a commitment to forging a more socially and environmentally fair city, designed by and for its residents, ABTS has been pivotal in reinforcing their agenda, both in the mass media and within local political arenas. The appointment of Ada Colau as Mayor has helped foster a more open debate on tourism-related issues and legitimized grassroots movements in the Barcelona Tourism and City Board.

Building upon sparse degrowth literature in tourism (Andriotis, 2014; 2018; Hall, 2009, Canavan, 2014), the 2000s saw the intensification of tourism related social movements and degrowth advocacy (Demaria, Schneider, Sekulova, \& Martinez-Alier, 2013), and investigations into the disruptive effects of the Barcelona model (Capel, 2005; Delgado, 2007; Milano \& Mansilla, 2018; Russo \& Scarnato, 2018). In this light, ABTS' activism and the extent to which this has influenced a shift, from "growth for development" to "degrowth for liveability" is explored. By drawing upon ethnographic research conducted in Barcelona between 2015 and 2018, and employing a Rapid Situation Analysis (RSA) participatory method based on in-depth and semistructured interviews, informal conversations, participantobservations and retrospective evaluations of field diary entries to identify emergent themes, this study adds to the unfolding critical literature regarding the links between overtourism, social movements and tourism degrowth.

\section{Degrowth and social movement in the age of overtourism}

A number of theoretical perspectives form the scaffold upon which empirical findings of this paper are discussed. As a phenomenon, overtourism can be viewed from a range of theoretical lenses including political economy, human geography, social anthropology, cultural studies, urban, rural and coastal planning, tourism marketing (and de-marketing) and destination management, to name just a few. In particular, the approach to the study of overtourism taken draws upon the juxtaposition of two key framing perspectives: degrowth (Kallis et al., 2018) and social movements theory (Castells, 1983). In both cases, the literature is diverse and longstanding, but rather than addressing these in minute detail, we acknowledge, integrate and investigate those dimensions relevant to critically assessing the relationship between overtourism, grassroots activism and the evolution of tourism degrowth campaigns. Importantly, the argument for degrowth is, to a large degree, driven from the bottom-up by advocates, activists and civil society groups for whom growth has proved to be disruptive, marginalising and has led to largely adverse outcomes. Overtourism is emblematic of the processes and outcomes of tourism growth, oftentimes rapid and unsustainable 
expansion, and in many cases, exogenously driven and embedded in the global travel supply chain that mostly operates outside the purview of destination communities

(Milano, Cheer, \& Novelli, 2018). Degrowth is largely a reaction to economic growth, where processes of consumption and production have become largely divorced (Kallis et al., 2018) and where supply chains proliferate through increasing extraction of underlying resources for productive gain, while costs of production are borne by communities and resource guardians.

As key proponents of degrowth, Kallis et al. (2018) contend, it is worth considering how reducing production and consumption might be possible without diminishing prosperity or wellbeing. Promoters of growth, mostly international agencies, government and private sector actors, characteristically spurn thoughts of economic contraction citing that expansion and resources exploitation is vital to maintaining standards of living and increasing incomes, and that overall, productivity is vital to economic stability (Beckerman, 1975). Indeed, productivity is considered the benchmark of what underpins a vibrant economy in much the same way that profitability is used to distinguish the performance and prospects of corporations - clearly emphasising economic indicators as the marker of prosperity. Yet, when growth takes little stock of non-economic considerations, this creates fertile ground for opponents of economic growth, especially civil society groups who find themselves on the periphery of the growth nexus, and often excluded from policy and planning processes or academic discourses.

In theorizing degrowth, Kallis et al. (2018) draw on political economy, political ecology and sustainable development concerns that underpin the clarion call for economic degrowth as a corollary toward more sustainable and just outcomes. This also speaks to growing global advocacy questioning consumptive patterns underpinned by economic growth and whether the pace and rate of change undermines the natural endowments for future generations. Kallis (2011) has been particularly vehement that sustainable degrowth should be foregrounded and given urgency within policy and planning discourses. Furthermore, he emphasises that "sustainable degrowth is not only an inevitable hypothesis, but also a potent political vision that can be socially transformative” (2011, p. 873). The coalescing of economic policy with social-ecological concerns is central to the degrowth thesis, calling for a commensurate focus to be given to the non-economic perturbations that are a direct result of economic growth.

Serge Latouche (2009), a key proponent in the development of degrowth scholarly discourses conceptualises that the thematic of delineating consumption growth and the extent to which this is enhancing human well-being or not is fundamental to degrowth advocacy. The question as to whether productivity gains are actually fostering human well-being or undermining prospects for the future is resonant in the degrowth putsch and is also echoed in the overtourism uprising as well. D'Alisa et al (2014, p. 25) throws into stark relief notions of degrowth and contends that "the idea of economic degrowth and of the construction of a society of sharing, frugality and conviviality continue to strengthen” is fundamental. However, although the limits to growth (Meadows, Meadows, Randers, \& Behrens, 1972) and the antigrowth movement were rooted into the political agendas of large cities in the 1970s (Molotch, 1976), whether degrowth advocacy has made material changes to policymaker and business attitudes to economic expansion orientations remains doubtful.

Social movements theory, as advanced by Castells (1983) and Touraine (1981) over four decades ago and new social movements theory by Beuchler (1995) and Anyon (2014) suggests that the mobilisation of grassroots actors and activists in organised activism is a vital response to problematic economic, socio-political and environmental changes that 
marginalise and undermine ecological endowments. The shift from proletarian movements toward collective action for a wider array of motivations underlines the progression of social movement theory (Beuchler, 1995). Zald and MaCarthy (1987) make the important distinction that while social movements were described as spontaneous banding of individuals, it is now a more common mobilisation in response to sociopolitical, economic and environmental grievances. This is evident in the rise of social movements in opposition to political (Yellow Umbrella Movement and the Anti-Consumerism Movement), economic (Occupy Wall Street), social (LGBTIQ rights) and environmental (Sea Shepherd/Greenpeace) causes seeking redress and/or reform to institutional inertia. The progression to what may be argued to be new "new social movements" is underlined in the Information Age where "networked social movements" (Castells, 2015) highly organized, share information and enact unprecedented digital strategies with more ease toward greater and more rapid impact.

Political and economic processes that have diminished agencies and wellbeing of particular populaces is especially pertinent, and more so where these have proved to be disruptive to public and private spaces or have undermined the commons. Social movement theory has a deep and diverse trajectory (Diani, 1992) and while it is beyond the remit of this paper to take a deep dive into what are evidently divergent perspectives, especially the binaries that exist between what it is and isn't, and the disciplinary leanings that prevail. Notwithstanding, social movement theory considers social movements as bottom-up activism predicated on rectifying problematic disjunctures that emerge in accordance with socio-political, economic and environmental transformation. This is in harmony with the links Zald and McCarthy (2017, p. 17) make with the term resource mobilization where "an increase in the extent or intensity of grievances or deprivation and the development of ideology occur prior to the emergence of social movement phenomena”. Moreover, this is especially discernible in the present where although global economic prosperity has reached unprecedented heights, sizeable cohorts remain adrift of such developments creating fertile grounds for discontent and grievances.

Castells (1983, p. xv) frames social movement making as "purposive social action" that is predicated on reform and rectifying perceived system failures that have impinged on the rights and wellbeing of interest groups. Diani (2007) refers to advocacy groups as "social movement networks" made up of individuals and networks with common aspirations around attaining positions of social justice, democratic reform, fairness and redress for circumstances often characterised by mismanagement, deficient planning and poor governance. In essence, Castells (1983, xvi) underlines that social movements are driven by "a reaction to a crisis created by an economically determined structural logic”. Similarly, Alvarez and Escobar (1992, p. 4) outline: "Social action is understood as the product of complex social processes in which structure and agency interact in manifold ways and in which actors produce meanings, negotiate, and make decisions”.

Social movements are essentially counterpoised against incumbent authority and sociopolitical and economic structures that have led to actors within such collectives baying for change that halts and to some degree, unwinds enduring and emergent institutional marginalisation and injustice. This disruption is exemplified by Owens (2008) who argues that very often, social movements are created by tensions from below that use, as their inspiration, the dissonance between government and business lobby interests and what they see as overriding imperatives of economic growth that leave them on the outer. These are common themes in social movement theory where thresholds of disempowerment and 
disenfranchisement spurs collective action aimed at remedying longstanding grievances that have slowly led to widespread injustices and expropriation of legacies from which actors within movements have enjoyed, leveraged, or inherited. This is exemplified in practice where displacement, exploitation and transformation have served to alienate and disadvantage members of movements.

Linking degrowth with social movements might be the aftereffect of how some contemporary social activism is predicated on growth and transformation that is disproportionately justified upon overarching economic rationale to maintain productivity, employment and income growth. This feeds into social movement opposition against neoliberal and globalization agendas that are framed by keeping financial markets stable and production and supply chains continuously in 'production mode'. The aversion to degrowth stokes fears of economic recession and threats to political longevity of governments and business viability of corporations, making ensuing contentions prone to politicisation and fear mongering.

In conflating overtourism with the dual theoretical underpinnings of social movement theory and principles of degrowth, what is evident is that social movements and degrowth are intertwined in the struggles that have ensued where host community tolerances and wellbeing have been breached by the collectivized actions of visitor economy growth (Owens, 2008). The displacement and alienating effects central to the angst that drives overtourism is intimately connected to calls for tourism degrowth. However, whether destination managers and the global travel supply chain can countenance such moves is questionable. Travel consumption is emblematic of wider consumptive trends underlined by economic prosperity and driven by the desire for greater mobility. What this means for social movements aligned against touristic endeavours suggests that there may be little for activists to be sanguine about.

\section{Social movements' touristification and tourism activism on the rise}

The fact that tourism requires political stability, security and public safety in order to flourish is firmly established in extant literature (Espiner, Orchiston, \& Higham, 2017; Stephenson \& Bianchi, 2014). In this context, activism in the form of social movements protests, demonstrations and/or strikes represent an anti-tourist element (Cordero Ulate, 2006). The relationship between tourism and the engagement with urban social movements is diverse and complex and needs to be investigated not only from the perspective of "exploitation and resistance to tourism", but rather as a dialectic process between all of the parties involved (Owens, 2008).

The twin domains of tourism and social movements studies have rarely been linked in scholarly investigations with the exception of Colomb and Novy (2016). However, in recent years, there has been a noticeable rise in activism driven by social movements and in their struggles and denunciations against tourism expansion, they have shifted concerns from the local to the global, with this convergence leading to reciprocal exchanges between tourism industry and social movements (Milano, 2017a). For instance, tourism can be both a target and a result of activism and, the latter can become a tourist attraction. For example, social movements have been employed for the promotion of tourism including political tourism, revolutionary tourism or Zapatourism in Mexico (Coronado, 2008; Garza Tovar \& Sanchez Crispın, 2015), militant and brigade tourism in Central America and as seen in Brazil's Landless Workers Movement's (MST) (Gascon, 2009), volunteer tourism in Palestine (Belhassen, Uriely, \& Assor, 2014; Isaac \& Platenkamp, 2010) and in volunteer tourism 
(McGehee, 2002; McGehee \& Santos, 2005), as well as NGO (non-government organisations) study tours and rights-based tourism (Spencer, 2008). Conversely, tourism has become the subject of what might be referred to as the touristification of social movements agendas, particularly in relation to tourism activism where overtourism has become a catch cry (Milano, 2018). In all, social movements have appropriated a critical discourse and spawned tourism-centred activism.

Historically, social movements have been centred on the struggle of workers against precarious working conditions, gender inequality, sex discrimination, healthcare services, social exclusion and the privatization of education (Cohen \& Rai, 2000). However, in recent decades, critical discourses specifically related to tourism and the wider visitor economy have become central to social movement narratives as evidenced in debates and at assemblies that appeal for action. At the same time, mainstream media discourses have provided wide coverage of overtourism describing evidently adverse impacts of tourism in cities. In emphasising urban settings, social movements have tended to gloss over tourism development in rural and coastal regions. However, the latter is not at all a new or less important area of concern. While in Southern Europe local environmental activism against tourism development emerged in the mid 1970s (Kousis, 2000), in Latin America there are many cases of popular mobilizations against tourism development in rural areas (Almeida \& Cordero Ulate, 2015), including actions of environmental groups related to climate change protests in Costa Rica (Cordero Ulate, 2015), local clashes to preserve native land rights in Panama (Maney, 2001), resistance to tourism mega-projects in indigenous territories in Northeast Brazil (Lustosa \& de Almeida, 2011) and denunciation of displacement, precarious labour and real-estate speculation in Mexico and Central America (Blazquez \& Ca nada, 2011; Ca nada, 2010; Hiernaux-Nicolas, 1999; Horton, 2007, Bonilla \& Mortd, 2008).

In urban settings specifically, the overtourism debate is embedded in growing criticism of tourism development models characterised by privatization and saturation of public spaces, inflationary effects on house prices and the resulting diminishment of resident purchasing power, outsourcing of employment leading to precarious working conditions and the transformation of the commercial fabric of cities that undermine essential characteristics of places. These have been instrumental in the "touristification of social movements" (Milano, 2018) agenda and of "urban tourism politicisation from below" in international tourist hotspots in Europe, North America, South America and Asia” (Colomb \& Novy, 2016, p. 5). In the 1990s Boissevain (1996) emphasised the disjunctures resulting from mass tourism in various southern European destinations and how local communities used tourism as a source of dispute through covert resistance, hiding, fencing, rituals, organized protests and aggression. More recently, mainstream media sensationalism and preoccupation with overtourism has legitimized critical discourses regarding tourism development and the relationship between social movements and tourism development cities. Conversely, academic discourses have been slower to undertake critical examinations. 
Table 1. Historical Milestones, 2004-2018.

\begin{tabular}{|c|c|}
\hline Year & Milestone Event \\
\hline $\begin{array}{l}2018 \\
2018 \\
2018 \\
2018\end{array}$ & $\begin{array}{l}2^{\text {nt }} \text { Forum Veinal sobre Turisme - Reflexions sobre turisme a Barcelona i el Sud d'Europa } \\
\text { SET Network press conference in Barcelona } \\
\text { Meeting: Neighbourhood Life - Tourist Tours. Can we share the space? } \\
\text { Meetina: Port-city: towards what model are we adootino? }\end{array}$ \\
\hline $\begin{array}{l}2017 \\
2017 \\
2017\end{array}$ & $\begin{array}{l}\text { Protest aqainst the opening of the first Gaud, I work "Casa Vincens" } \\
\text { Protest against the arrival of the biggest cruise ship of the world "Symphony of the Seas" } \\
\text { Demonstration against the opening of a new Port Terminal } \\
\text { A group of youths' slashes tyres on sightseeing bus and rental bikes in Barcelona }\end{array}$ \\
\hline $\begin{array}{l}2016 \\
2015\end{array}$ & $\begin{array}{l}\text { 1: } F \text { Forum Veinal sobre Turisme }-C_{3} \text { tica, an alisi i proposte } \\
\text { Constitution of ABTS }\end{array}$ \\
\hline $\begin{array}{l}2008 \\
2004\end{array}$ & $\begin{array}{l}\text { El Po, snewspaper publishes an article titled "Turistofobia", written by Manuel Delgado } \\
\text { Universal Forum of Cultures held in Barcelona provokes discontent among residents }\end{array}$ \\
\hline
\end{tabular}

Lastly, the interrelationships between urban social movements and tourism can be seen aspractice-based predicated on a twofold rule of engagement; firstly, by established social movements pointing to tourism as the cause of existing discontents and inequalities due to gentrification, displacement and/or housing crises, and secondly through the ad hoc constitution of social movements specifically aimed at tourism activism, such as the ABTS. It is worth noting that the actors participating in such activism are distinct from the classic revolutionary factory workers commonly referred to in Keynesian discourses and instead, are associated with middle-class urbanities struggling to maintain and preserve their quality of life amidst contemporary postindustrial neoliberal contexts (Mayer, 2012).

\section{Research context}

Barcelona has become one of the globe's most visited tourist cities with the initial tourism growth spurt taking place during the urban transformations that ensued prior to the summer Olympics Games in 1992 and the establishment in 1993 of the public-private Consortium of Turisme de Barcelona, a tourism marketing agency of the city. The nineties marked a point from which Barcelona embarked on the trajectory to become one of the urban tourism capitals of Europe (Lopoz-Palomeque, 2015; Palou, 2011). This is unsurprising given the breadth and spread of tangible and intangible culture and the historic backdrop that underpins the city. In particular, the city's inimitable architecture and design (Borja, 2010) together with the spread of services, technology, urban marketing and tourism placemaking (Lew, 2017; Mansilla, 2016; Mansilla \& Milano, 2019) catapulted it into the European practice of commodifying cities. The so-called "Barcelona Model” (Capel, 2005; Delgado, 2007) and the intensifying city tourism growth is central to upsurge in grassroots activism.

Concerning social movements' activism against tourism, the summer of 2017 is remembered as a watershed of protests against mass tourism that occurred in several Spanish cities (Hughes, 2018). However, the root cause of such discontent is arguably found in much earlier debates at events such as the Universal Forum of Cultures, an international event that took place in Barcelona in 2004; it had three main themes including cultural diversity, sustainable development and conditions for peace. This event is arguably a milestone (see Table 1) of the controversial relationship between Barcelona's citizens and tourism, concerned about the city's capacity to absorb more tourists, and wanting to strike a balance between residents' 
everyday life and tourism (Sunol, 2016). Since then, the focus of social movements against tourism has shifted and is now characterised by activism with ABTS at the helm. ABTS has concentrated on mobilising voices of neighbourhood cohorts on issues such as reversing the triumphalist tourism discourse rooted in production and consumption growth models, the alleviation of pressures from real estate speculation and rising housing costs, as well as emphasizing tourism degrowth.

On July 1st 2016, the first Neighbourhood Forum on Tourism (Foro Vecinal sobre Turismo) was hosted in Barcelona and resulted in acknowledgement of the need to address overtourism and facilitate closer ties with counterparts in Venice, Mallorca, Camp de Tarragona and Malaga. Two years later, on May 18th and 19th 2018, neighbourhood associations, social movements and activist groups from 14 southern European cities convened in Barcelona for the second Neighbourhood Forum on Tourism (Foro Vecinal sobre Turismo) under the theme "Tourism reflections on Barcelona and South Europe". This resulted in the constitution of the Network of Southern European Cities against Touristification (SET Network). SET initially comprised of social movements from sixteen places - Venice, Valencia, Sevilla, Pamplona, Palma de Mallorca, Malta, Malaga, Madrid, Lisbon, Florencia, Ibiza, Girona, San Sebastian, Canarias, Camp de Tarragona and Barcelona. By adopting a synergic approach, SET's main goal is to engage in joint actions of protest against the "growth centred model" of urban tourism and apply pressure on national governments to promote degrowth.

\section{Methodology}

This study is comprised of a team of three researchers including an established "insider" (who has been a resident in Barcelona since 2008) and two "outsiders" (Beebe, 2001). The value of having long-term field research conducted by an "insider" with extensive research experience in the destination provided a high level of trust with local communities, allowed unique access to key stakeholders and enabled the employment of snowball sampling. Critical reflections on the evolution of social movements discourses were gleaned from the first Neighbourhood Forum on Tourism (Foro Vecinal sobre Turismo) in 2016, by the "insider" and was instrumental in identifying key historical milestones (see Table 1) and in tracking the evolution of social movements. Importantly, however, these reflections were mediated and reviewed through probing questions by "outsider" counterparts, who had more "distance" from the effects of overtourism and social movements based in other geographical locations.

Drawing upon evidence emerging from ethnography conducted in Barcelona between 2015 and 2018, this article reports on fieldwork undertaken in informal settings using Rapid Situation Analysis (RSA) as an overarching research approach. RSA is a tried and tested (Novelli, Morgan, Mitchell, \& Ivanov, 2016) "hybrid, participatory, bottom-up [qualitative and interpretative] research approach” (Koutra, 2010, pp. 1016). The analysis of participants in situ allows for a more nuanced and critical investigation of the complex dynamics associated with overtourism and social movements and their promotion of degrowth in Barcelona. RSA interprets and consolidates feedback from local participants which, when shared with the community, allows for reflection, ownership and transformation (Koutra, 2010). The research in this case consisted of four stages realized between 2015 and 2018: 
Stage 1 - Desk research of secondary data sources including government statements, social movements manifestos and websites, city council reports and plans, press releases, social media network discourses

Stage 2 - In depth semi-structured interviews with social movement agents in Barcelona

Stage 3 - Overt participant observations and informal conversations during workshops, stakeholder consultations, assemblies and meetings

Stage 4 - Retrospective analysis of field diary entries based on fieldwork and informal conversations with respondents

The main intention was to employ participatory research methods with social movement actors to explore their attitudes toward overtourism and degrowth. Concurrent to the participatory research undertaken in Barcelona, fieldwork was conducted during social movements events in other places as part of the SET Network. These included the 'Social movements facing tourism’ event in Mallorca in June 2017 (Moviments socials davant el turisme. Una lluita compartida a diferents territoris i ciutats) and in San Sebastian in May 2018 - 'The effects of tourism on San Sebastian inhabitants daily life' (Los efectos del Turismo en la vida de las donostiarras). Further fieldwork interviewing stakeholders with differing levels of influence and interest, and with a geographical spread across various neighbourhoods of Barcelona commenced in July 2016 during the first Neighbourhood Forum on Tourism (Foro Vecinal sobre Turismo) and throughout the period that led to the second Neighbourhood Forum on Tourism (Foro Vecinal sobre Turismo) in May 2018, through to August 2018.

While reflexive analysis of field diary entries to identify emergent themes and participant observation records framed evidence of social movements activities during the period under investigation, in-depth semi-structured interviews allowed participants to provide deep insights into their experience with tourism activism. This allowed data triangulation with field diary entries and participant's observational findings.

Initial focus was on research questions that contribute to understanding how and why events occurred and evolved, rather than testing a hypothesis with theory derived from generated data (Hart, 1998; Robson, 2011). The interpretation of overtourism by social movements lends itself to a holistic inductive research design focused on the adoption and evolution of the degrowth concept in Barcelona as a series of complex inter-related components rather than assessing individual parts (Armstrong, 2008). Interviews were conducted between 2016 and 2018 with residents ( $\mathrm{n} 1 / 47$ and coded R1 to R7) and social movement activists from Barcelona international activists from SET Network members (n⿳⺈⿴囗十 8 and coded SMA1 to SMA8). In addition, field diary notes were compiled during participant observation and fieldwork (coded FD1).

Targeted research participants were recruited at assemblies, demonstrations and specific events for interviews, with an indication of the focus provided beforehand comprised of guiding questions. Although a set of predetermined questions had been identified, and was aimed at determining the participants' connection with tourism activism in Barcelona, the priority was to enable research participants to guide conversations and to provide insight into their own experiences. Participants were encouraged to engage through open conversations that aided the establishment of a healthy rapport and trust, which proved invaluable when 
analysing, interpreting and contextualizing the interview transcripts. To aid the data recording process, participants' permission was sought to tape-record interviews and undertake notetaking. Although most of the participants did not ask for anonymity, all were coded for consistency. The interviews were transcribed and analysed using direct content analysis to "identify core consistencies and meanings", which guided the identification of themes (Patton, 2002, p. 453). Direct content analysis was employed in the evaluation of the personal diary entries, which supplemented the data collection process. Photographic evidence supplemented interviews providing visual evidence and record of events. Interviews lasted between thirty minutes to an hour and were conducted in Spanish, Portuguese and Italian in line with the nationalities of social movements.

\section{Findings: the tourism degrowth campaign}

The ensuing findings highlighted how tourism degrowth had evolved and how it entered social movement discourses led by the ABTS in Barcelona and the subsequent spread internationally through the SET Network. Overarching findings suggest that hitherto, the tourism degrowth campaign was strictly related to deep-rooted social unrest associated to overtourism concerns.

\section{(1) Tourism growth, overtourism symptoms and social unrest}

In Barcelona, recent decades have been characterized by tourism growth-oriented policies that have fostered foreign investment, tourism-oriented infrastructure development, city branding policies and proliferation of housing for touristic use (HUT). The related transformations have fed social unrest and the diminishment of Barcelonans liveability and wellbeing related to housing and cost of living pressures, congestion of public transport and the exclusivity of tourist related shops.

While overtourism concerns are usually related to the transformations caused by tourism massification, transformation in cities is unavoidable and occurs irrespective of tourism. For instance, as stated by a resident: "the reality of a city is the transformation and the only immutable thing in a city or in an urban space is change (...) but what has happened in the Gothic Quarter is brutal, what happened in Barceloneta is brutal and what is happening in Sant Antoni can only be dangerous” (R1). In mid-May 2018, the Sant Antoni Market reopened after nine years of renewal works and the official unveiling was met with protests and concerns against gentrification processes that the refurbishment of the market provoked. Furthermore, the issue of how overtourism may affect residents' sense of belonging emerged social movement activist statements: "we are talking about residents with the ability to create a community. Everything changes but it's not about nostalgia. We are Mediterranean, we are used to physical relationships with spaces as we need a place to have coffee or a beer. We need our neighbourhoods" (SMA2).

Importantly, social movement claims are not just related to tourism-related concerns: 'the main objective is to combat gentrification and for the defence of more inclusive neighbourhoods" (R2). According to a social movement activists, the social unrest in Barcelona is not as recent as one may think. It started in 2000 with "a concern about the purchase of [residential] apartments, which were turning into tourist accommodations (...) and in that moment it was more a concern of coexistence about the different lifestyles of people who come for tourism purpose and people who have a daily routine” (SMA2). 
Currently, criticism and social unrest has evolved, as exemplified in a resident's statement: "I can see a change in the ideological proclamations and the combative struggle of an elite with an alternative rebel attitude, still I don't know if for everyone is clear what gentrification or touristification means” (R1).

\section{(2) It's not tourismphobia - this is just an attempt to discourage critical discourse}

More recently in 2015, ABTS encouraged a more consistent narrative and awareness about the overtourism social unrest, both in the media and in the political arena. Its most significant discourse revolves around tourism degrowth in the city of Barcelona (Figure 1). ABTS agenda have become more visible also as a result of academic and activists' collaborations (Cocola-Gant \& Pardo, 2017), press exposure, through the dissemination of scientific publications (Medrano \& Pardo, 2016) and as a result of the formation of a research group on degrowth tourism that meshes the participation of researchers, activists and residents.

During the meeting Neighbourhood Life - Tourist Tours. Can we share the space? held in Barcelona the 9th of February, 2018 with some fifty participants, including tourist guides and residents, the discussion addressed the congestion of public space in the Gothic Quarter due to the proliferation of independent and guided walking tours. A member of AGUICAT (Association of Tourist Guides of Catalonia) highlighted that only a small number of tour guides were practicing sustainable ways to guide tours that did not contribute to the congestion of public spaces (FD1). The AGUICAT code of good practice for walking tours that minimize annoyances to local residents includes: keep small groups and avoid busy areas, use the wireless whispers audio system to avoid noise pollution, do not interfere with daily local life of locals by taking photos and respecting privacy and safety as well as avoiding long explanations in congested areas.

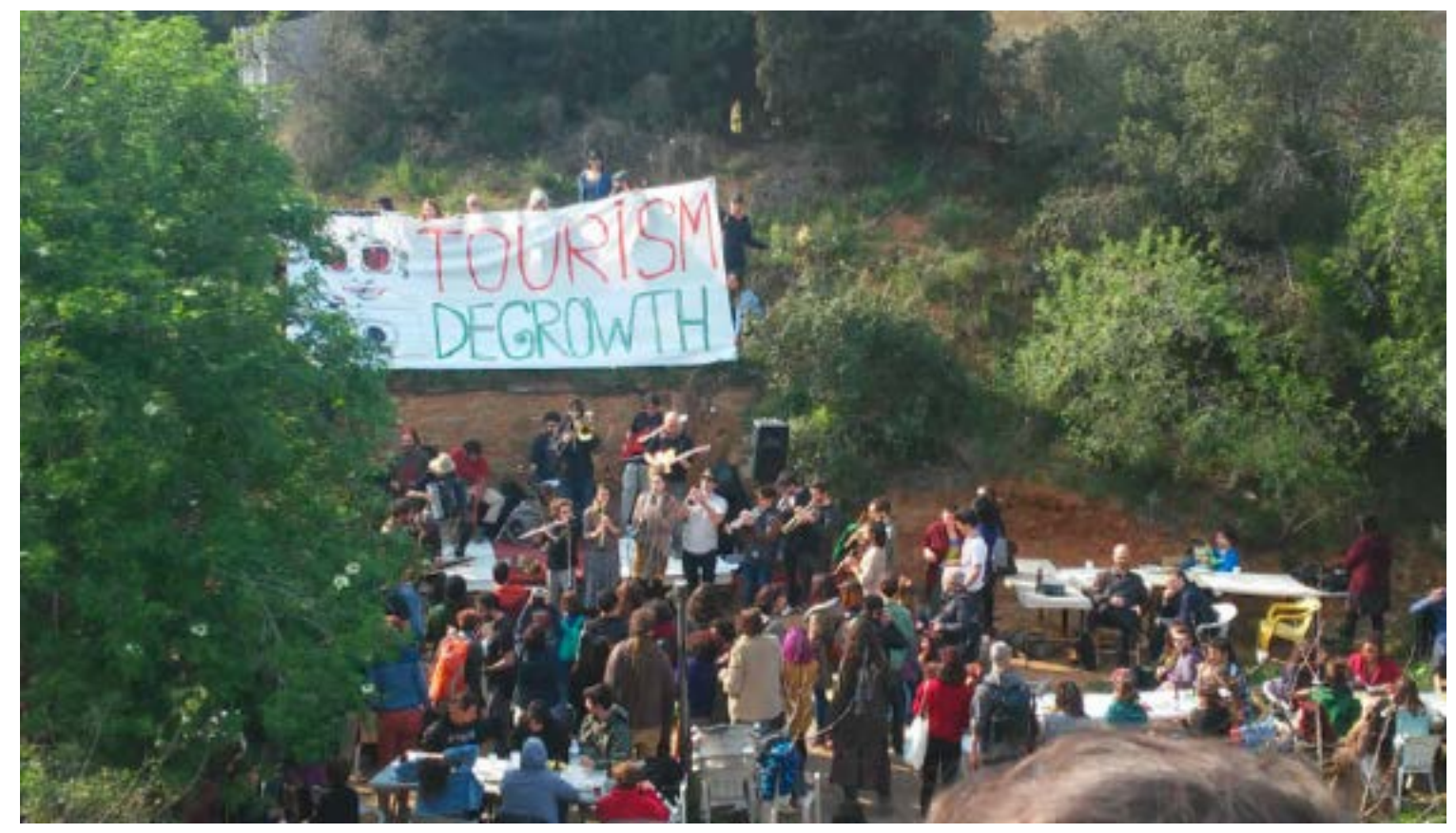

Figure 1. Tourism degrowth event organized in Barcelona, 12 March, 2017 (Source: ABTS Photoreporters).

By inferring to the need for tourism degrowth associated with the emergence of intolerant behaviours towards tourists, a respondent concluded, "there is no tourismphobia, but [there 
is] an aggression to the public space and civic coexistence, which requires immediate attention” (FD1). Furthermore, a social activist stated: “tourismphobia has been an invention of the tourism industry, which stigmatized dissidences. There have been attempts to discourage the critical discourse with the conception of a negative new term. The problem is not tourism, but all the circumstances surrounding that [the phenomenon]” (SMA3).

Activism in Barcelona related to overtourism social unrest maintains a controversial dualism. While on one hand, overtourism criticism has been tainted by media sensationalism (see Figure 2) and has promoted the use of the word tourismphobia deflecting attention from genuine social movement concern. For instance, the social media bubble on tourismphobia, that exploded during the summer of 2017 coincided with the denouncements for improved labour rights in the hotel sector by housekeepers' unions and professional associations (Ca nada, 2015; 2018), thus directing attention elsewhere. Conversely, tourismphobia has given greater visibility to the struggles of service workers and fostered the introduction of tourism degrowth into political debates and urban planning agenda. According to social movement respondents, their focus on tourism started in Barcelona in the middle of the last decade and is used to refer to their 'specialization in tourism issues' (SMA1; SMA3). It is this specialization that has facilitated the introduction of degrowth as a potential solution to the objections of social movements.

\section{(3) Tourism degrowth is not just a technical solution}

On many occasions, Barcelona's social movements, led by ABTS, have criticised public policies aimed at addressing overtourism as simplistic through their 'one size fits all' technical approach, rather than dealing with the underpinning causes in a more strategic manner. As a result, degrowth became their preferred way forward. In this regard, the individual use of the 5D's - Deseasonalization, Decongestion, Decentralization, Diversification and Deluxe tourism have been criticised as neoliberal strategies that do not address the many factors that have led to overtourism (Milano, 2018). This reductive and simplistic approach is considered (SMA2 and SMA3) 

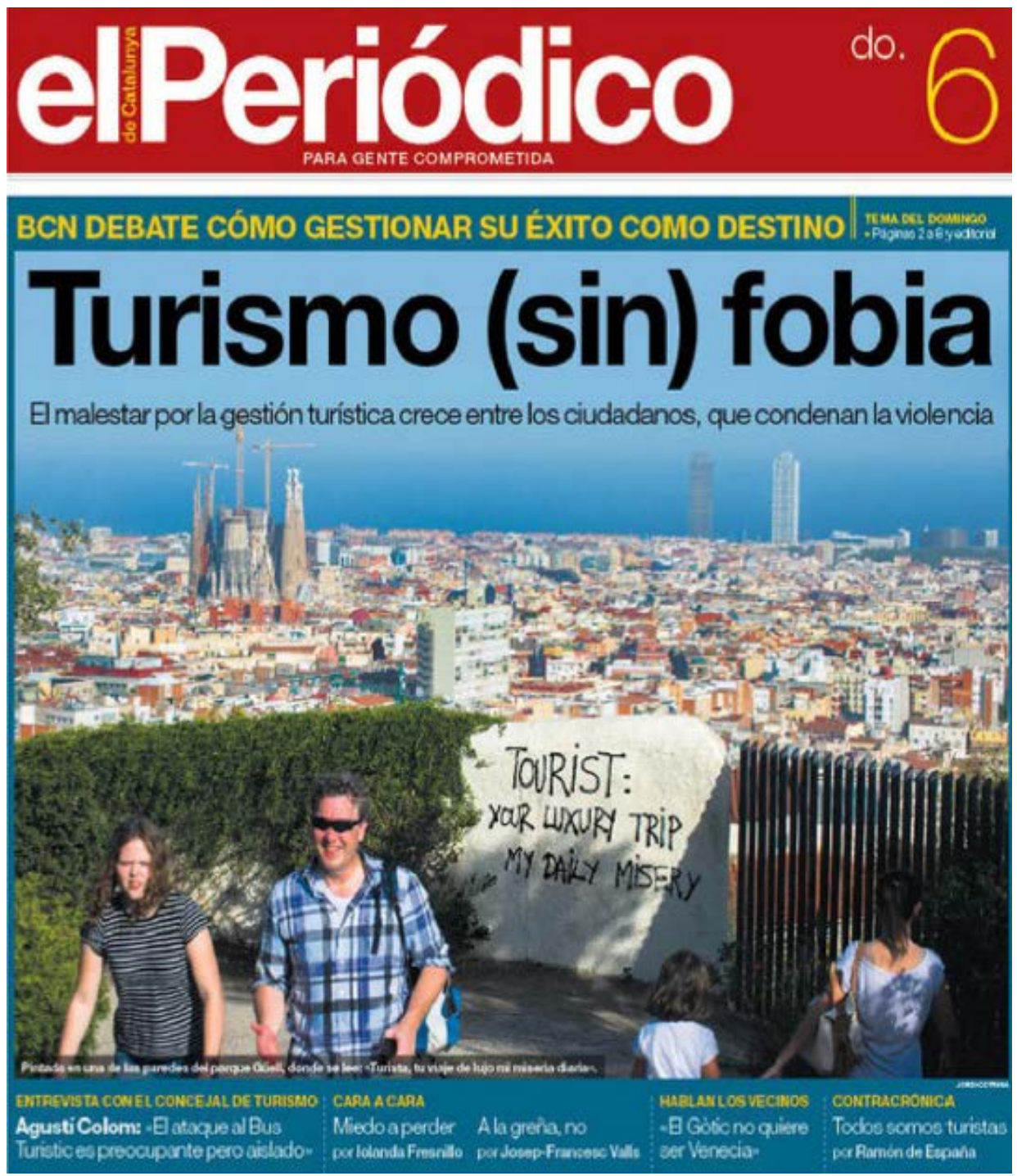

\section{Figure 2. Front Page El Periodico 6 August 2017 (Source: El Periodico).}

inadequate on the basis that each of the 5Ds, if taken in isolation, remain short-term solutions that does not sufficiently deal with the underlying complexity of urban tourism governance.

Overwhelming sentiments from respondents is that to achieve tourism degrowth and a paradigm shift in the way tourism success is measured can't be addressed with isolated technical solutions. Overtourism is not only a tourism issue and is part of a wider urban planning agenda. While the 5D's technical approach might not epitomise a profound change. According to the ABTS and SET Network, any technical solution needs encompass degrowth as part of the political landscape. Degrowth has been widely promoted by the ABTS in several instances (i.e. stakeholders meeting, neighbourhood associations, assemblies and in peaceful demonstrations). The first example of synergic social movements intervention promoting tourism degrowth was the $1^{\text {st }}$ Neighbourhood Forum on Tourism, held in Barcelona in 2016, that gathered international social movements such as No Grandi Navi from Venice. The event addressed controversial issues such as the employment of residential properties and public space for tourism, the proliferation of growth oriented economic models, and poor governance of cruise tourism as seen in the administration of Barcelona 
Port. At the Forum, the ABTS identified a number of challenges and proposed ten key principles to effectively engage in tourism degrowth. These are summarized in Table 2.

Table 2. ABTS' ten key principles towards tourism degrowth (Source: adapted from ABTS, 2016).

\author{
ABTS' ten key principles towards tourism degrowth \\ (1) Identify specific data that validates that tourism impacts in Barcelona are understood \\ (2) Develop an index that enables the measurement of the quality of life in cities \\ (3) Foster a debate on tourism between different critics' actors and stakeholders \\ (4)Run campaigns to raise awareness of tourism's impacts \\ (5) Establish local representation on the Barcelona Port Authority Administration Board \\ (6) Propose alternative models to Port management \\ (7)Establish a tourist tax to address the negative impacts of tourism in the city \\ (8) Promote a public platform to endorse legislation for the management of areas close to the Port not currently controlled by \\ the City Council \\ (9) Develop an integrated Port Plan \\ (10) Promote better coordination among social movements, and internationalize initiatives
}

Table 3. Measures aimed at tourism degrowth in Barcelona (Source: SMA1).

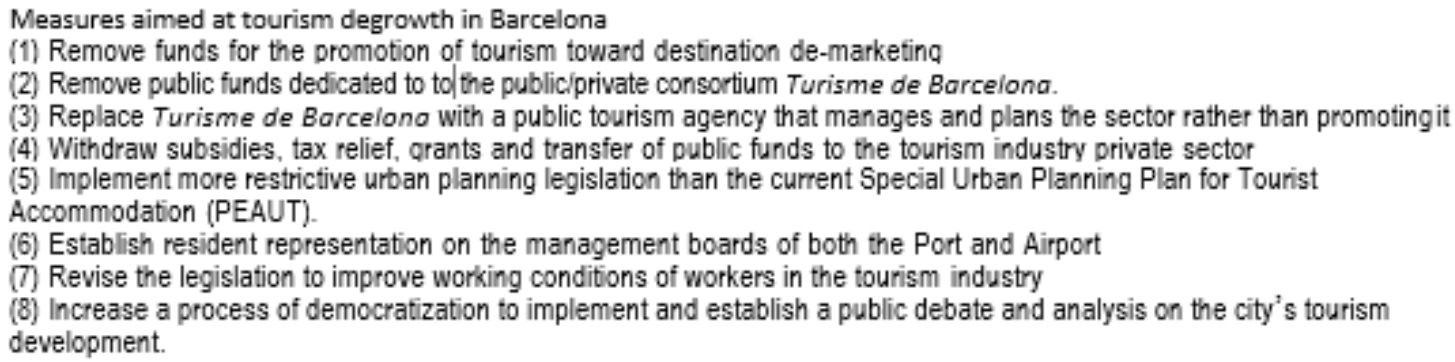

These were identified as urgent actions to be tackled by various stakeholders (R4, SMA2, SMA3; SMA4; SMA5), and these principles were further elaborated into a set of measures aimed at tourism degrowth in Barcelona by ABTS and SET Network members (SMA1) (See Table 3).

Overall, the aforementioned tourism degrowth principles and measures appear as the only acceptable ways to tackle overtourism. As emphasized by respondents: 'The only solution is degrowth (...) we must stop financing tourism promotion with public funds, abolish any public subsidy, direct and indirect, to the tourism industry and the famous taxes needs to be multiplied in a broader sense of responsibility and sustainability and not just as a greenwashing. Those are polluting companies, just as the rest” (SMA2).

\title{
(4) The campaign went global: the SET network
}

ABTS led activities in Barcelona and the tourism degrowth campaign (\#Decreixement turistic), was accompanied by the summer of 2017 campaign \#CapMesEstiuComAquest (No more summers like this), that denounced the effects of tourism continuing to grow at an increasing rate. In 2017, these campaigns went beyond Barcelona's boundaries with the constitution of the SET Network convoyed through several international meetings, such as the June 2017 "Social movements against tourism - a battle shared between different regions and cities" in Mallorca that gathered different social movements from European cities to discuss overtourism concerns. The event was attended by Comitato No Grandi Navi from Venice, Oficina de Urbanismo Social from Lavapies neighbourhood in Madrid, Sindicato de 
Inquilinos from Madrid, Assemblea Ciutat per qui l'Habita from Mallorca, Morar em Lisboa from Lisbon, Entre Barris from Valencia and the Assemblea de Barris per un Turismo Sostenible (ABTS) from Barcelona.

The ABTS tourism degrowth campaign provoked a snowball effect among southern European social movements, resulting in the constitution of the SET Network to cope with a growing global phenomenon. During the first press conference of the 26th April 2018 event, the SET manifesto (SET, 2018) highlighted pressing issues such as: the decrease of available housing for residents; the transformation of local trade patterns (i.e. souvenirs shops replacing local food shops); the congestion of public space (i.e. streets and square) and public transport; the specialization of the city's economy on servicing tourism (i.e. mushrooming of restaurants); the precariousness of working conditions; the generation of high pollution (i.e. increased arrival of airplanes, cruise ships and coaches) and waste; the unintended usage of public infrastructure (i.e. roads, ports, airports, etc.) and the stereotyping of both urban and natural destinations.

The SET network is emblematic of a social movements network emerging from the interactions of different nodes and actors (Diani, 2007; Castells, 2015). These synergies and networks have also meant a coordination of actions between various social movements that have led the awakening of social unrest associated with overtourism in southern European cities. In Italy there were two national meetings in 2018 that were attended by several Italian cities that make up the SET Italian Network. During interviews and informal conversations with activists from Venice (SMA4), Madrid (SMA5), Lisbon (SMA6), Florence (SMA7; SMA8) and Naples (FD1), the need for tourism degrowth and a deceleration of tourism promotion were emphasised.

\section{Conclusions}

Overtourism is conceived by respondents to this study as a shared responsibility among the various stakeholders, and in particular, city administrators and destination managers can have a considerable influence. The tourism value chain involves a complex urban governance system based on urban transport and mobility, housing, public health, public space, direct and indirect employment and other daily social practices. In Barcelona, social movements fostering an interventionist approach to overcome the overtourism phenomenon has evolved into the ABTS and its intensive programme of resistance, as well as the advancement of a SET Network agenda aimed at a tourism degrowth based on tighter regulation of the tourism sector.

Evidently, while a 'one size fits all' approach is regarded as not creating any useful and enduring change, dealing with overtourism remains a complex endeavour, requiring strategic deliberations and decision making that is necessarily contentious. The tourism degrowth discourse is claimed by social movements interviewed and observed in this research as the only way forward. However, the implementation of suggested measures (see Tables 1 and 2) would represent an unprecedented scenario and may remain largely aspirational, as inciting a tourism crisis will mean substantial economic repercussions for those who rely directly and indirectly on the tourism sector.

What is also clear is that strategies based only on tourism degrowth may not be sufficient to fully shift from a sector engrained with the 'growth for development' paradigm, to a 
'degrowth for liveability' one, and it may be too optimistic to think that such an approach could cope with the underlying complexity of urban tourism settings. The complementarity of the degrowth approach with 5D's - Deseasonalization, Decongestion, Decentralization, Diversification and Deluxe tourism, may therefore, provide a more context-adaptable and effective tool to deal with overtourism, but only if approached within the wider urban agenda. Tourism is a vital vehicle for creating the conditions of production and reproduction of capital, as well as only one of the forces that configure a contemporary city within new urban mobilities (Figure 3).

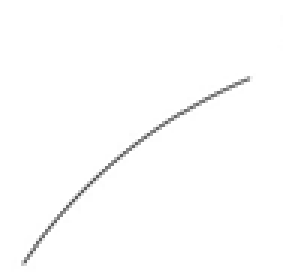

Deseasonalization

\section{Deluxe Tourism}

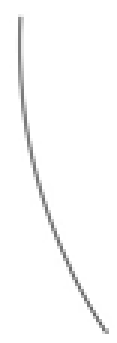

Diversification

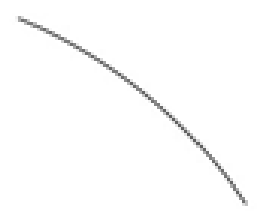

Decongestion

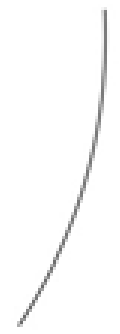

Decentralization

\section{Figure 3. 5Ds}

Further research in this regard would advance understandings of the controversial interrelationship between overtourism, degrowth and grassroots organization resistance. A social movements perspective and mass media communication analysis can help future research to shed light on the reasons why overtourism has become a contemporary issue in most tourist cities. Beyond the sensationalist journalism, tourism degrowth campaigns offer the opportunity to re-open a pressing debate on the exploitation of finite resources, limits to growth, the looming climate emergency and the recent emergence of flight shaming that questions the ethics of flying.

To achieve a substantive paradigm shift in urban tourism governance, both technical solutions and political will to act against overtourism are required. Tourism is one of many intrinsic components of the daily life of cities such as Barcelona and any degrowth potentially threatens the status quo the challenge for policy makers, academics, private stakeholders and grassroots organizations remains understanding how to live with the hypermobility of contemporary societies and the capital accumulation processes of inner cities characterized by a wider range of social actors such as regular and temporary residents, tourists, digital 
nomads, daily visitors, cruise passengers, international students, commuters, which are all seeking experiences and claiming different rights to the city. Encouraging a dialogue on the inclusiveness of our cities is of paramount importance and the current tourism degrowth campaign led by the ABTS in Barcelona and by the SET Network internationally is helping to facilitate a recharged debate on the limits of acceptable tourism growth internationally.

\section{References}

ABTS - Assemblea de Barris per un Turisme Sostenible (2016). Conclusions del I F $\square$ orum Veïnal sobre Turismo. [Conclusions of the I Neighborhood Forum on Tourism] Retrieved from: https://assembleabarris.files.wordpress.com/2016/08/conclu.pdf

Almeida, P., \& Cordero Ulate, A. (Eds.). (2015). Handbook of social movements across Latin America.Dordrecht: Springer.

Alvarez, S. E., \& Escobar, A. (1992). Conclusion: Theoretical and political horizons of change in contemporary Latin American social movements. In A. Escobar, (Ed.), The making of social movements in Latin America (pp. 317-331). New York, NY: Routledge.

Andriotis, K. (2014). Tourism development and the degrowth paradigm. Turisticko Poslovanje, 2014(13), 37-45. doi:10.5937/TurPos1413037A

Andriotis, K. (2018). Degrowth in Tourism: Conceptual, Theoretical and Philosophical Issues. Oxfordshire: CABI.

Anyon, J. (2014). Radical possibilities: Public policy, urban education, and a new social movement. London: Routledge.

Barcelona City Council (2016). Barcelona Strategic Tourism Plan for 2020. Tourism Department Manager's Office for Enterprise and Tourism.

Beckerman, W. (1975). Two Cheers for the Affluent Society: A spirited defense of economic growth. New York, NY: Saint Martin’s Press.

Beebe, J. (2001). Rapid assessment process: An introduction. Altamira: Rowman.

Belhassen, Y., Uriely, N., \& Assor, O. (2014). The touristification of a conflict zone: The case of Bil'in. Annals of Tourism Research, 49, 174-189. doi:10.1016/j.annals.2014.09.007

Blanco-Romero, A., Blazquez-Salom, M., \& Canoves, G. (2018). Barcelona, Housing Rent Bubble in a Tourist City. Social Responses and Local Policies. Sustainability, 10(6), 2043. doi:10.3390/su10062043

Blazquez, M., \& Canada, E. (Eds.). (2011). Turismo placebo: nueva colonizacion tur $\square$ 1stica del Mediterraneo a

Mesoamerica y el Caribe, logicas espaciales del capital turistico. [Tourism placebo: New tourist colonization of Mesoamerica and the Caribbean, space logic of tourist capital] Managua: EDISA.

Boissevain, J. (Ed.). (1996). Coping with tourists: European reactions to mass tourism (Vol. 1). Berghahn Books. 
Bonilla, A., \& Mortd, M. (2008). Turismo y conflictos territoriales en el Pacifico de Nicaragua: El caso de Tola, mas alla de los titulares. [Tourism and territorial conflicts in the Nicaraguan Pacific: The case of Tola, beyond headlines]. San Salvador: Fundacion Prisma.

Borja, J. (2010). Luces y sombras del urbanismo de Barcelona. [Lights and shadows of Barcelona's urbanism] Barcelona: UOC Edicions.

Buechler, S. M. (1995). New social movement theories. The Sociological Quarterly, 36(3), 441-464. doi:10.1111/j.1533-8525.1995.tb00447.x

Butler, R. W. (1980). The concept of a tourist area cycle of evolution: Implications for management of resources. The Canadian Geographer/Le Geographe Canadien, 24(1), 5-12. doi:10.1111/j.1541-0064.1980.tb00970.x

Canavan, B. (2014). Sustainable tourism: Development, decline and de-growth. Management issues from the Isle of Man. Journal of Sustainable Tourism, 22(1), 127-147.

doi:10.1080/09669582.2013.819876

Canada, E. (Ed.). (2010). Turismo en Centroam $\square$ erica: nuevo escenario de conflictividad. [Tourism Central America: New scenario of conflict] Managua: Enlace Editorial.

Canada, E. (2015). Las que limpian los hoteles. Historias ocultas de precariedad laboral. [Those who clean the hotels. Hidden stories of job insecurity] Barcelona: Icaria/Antrazyt.

Canada, E. (2018). Too precarious to be inclusive? Hotel maid employment in Spain. Tourism Geographies, 20(4), 653-674. doi:10.1080/14616688.2018.1437765

Capel, H. (2005). El Modelo Barcelona: Un examen critico. [The Barcelona model: A critical examination] Barcelona: Ed. Del Serbal.

Castells, M. (1983). The city and the grassroots: A cross-cultural theory of urban social movements (No. 7). Berkeley: Univ. of California Press.

Cheer, J. M. \& Lew, A. (Eds.) (2018). Tourism resilience and sustainability: Adapting to social, political and economic change. London: Routledge.

Cheer, J. M., Milano, C., \& Novelli, M. (2019). Tourism and community resilience in the Anthropocene: Accentuating temporal overtourism. Journal of Sustainable Tourism, 27(4), 554-572. doi:10.1080/09669582.2019.1578363

Cocola-Gant, A., \& Pardo, D. (2017). Resisting tourism gentrification: The experience of grassroots movements in Barcelona. Urbanistica Tre, Giornale Online di Urbanistica, 5(13), 39-47.

Cohen, R., \& Rai, S. M. (2000). Global social movements. Athlone Press.

Colomb, C., \& Novy, J. (Eds.) (2016). Protest and resistance in the tourist city. London: Routledge.

Cordero Ulate, A. (2006). Nuevos ejes de acumulacion y naturaleza. El caso del turismo. [New aspects of accumulation and nature. The tourism case]. Clacso: Buenos Aires. 
Cordero Ulate, A. C. (2015). Forest, water, and struggle: environmental movements in Costa Rica. In Almeida, P., \& Cordero Ulate, A. (Eds.). Handbook of social movements across Latin America (pp. 255-271). Dordrecht: Springer.

Coronado, G. (2008). Insurgencia y turismo: Reflexiones sobre el impacto del turista politizado en Chiapas. [Insurgence and tourism: Reflections on the impact of politicized tourist in Chiapas]. Pasos Revista de Turismo y Patrimonio Cultural, 6(1), 53-68. doi:10.25145/j.pasos.2008.06.005

D’Alisa, G., \& Demaria, F., \& Kallis, G. (Eds.). (2014). Degrowth: A vocabulary for a new era. London: Routledge.

Delgado, M. (2007). La ciudad mentirosa. Fraude y miseria del "Modelo Barcelona”. [The lying city. Fraude and misery of the "Barcelona Model"] Madrid: Los libros de la Catarata.

Demaria, F., Schneider, F., Sekulova, F., \& Martinez-Alier, J. (2013). What is degrowth? From an activist slogan to a social movement. Environmental Values, 22(2), 191-215. doi:10.3197/096327113X13581561725194

Diani, M. (1992). The concept of social movement. The Sociological Review, 40(1), 1-25. doi:10.1111/j.1467-954X.1992.tb02943.x

Diani, M. (2007). Social movements, networks and. The Blackwell Encyclopedia of Sociology.

Doxey, G. V. (1975). A causation theory of visitor/resident irritants: Methodology and research inferences. Proceedings of the Travel Research Association 6th Annual Conference (pp. 195-198). San Diego, CA: Travel Research Association.

Escobar, R. (2014). Development, critiques of. In G. D’Alisa, F. Demaria \& G. Kallis (Eds.), Degrowth: A vocabulary for a new era (pp. 29-32). New York, NY: Routledge.

Espiner, S., Orchiston, C., \& Higham, J. (2017). Resilience and sustainability: A complementary relationship? Towards a practical conceptual model for the sustainabilityresilience nexus in tourism. Journal of Sustainable Tourism, 25(10), 1385-1400. doi:10.1080/09669582.2017.1281929

Fletcher, R. (2011). Sustaining tourism, sustaining capitalism? The tourism industry's role in global capitalist expansion. Tourism Geographies, 13(3), 443-461.

doi:10.1080/14616688.2011.570372

Gant, A. C. (2016). Holiday rentals: The new gentrification battlefront. Sociological Research Online, 21(3), 1-9. doi:10.5153/sro.4071

Garza Tovar, J. R., \& Sanchez Crispın, A. (2015). Estructura territorial del turismo en San Cristobal de las Casas,

Chiapas, Mexico. [Tourism territorial structure in San Cristobal de las Casas, Chiapas, Mexico]. Cuadernos de Turismo, (35), 185-209. doi:10.6018/turismo.35.221571

Gascon, J. (2009). El turismo en la cooperacion internacional: De las brigadas internacionalistas al turismo solidario. [Tourism in international cooperation: Internationalist brigades for solidarity tourism] Barcelona: Icaria. 
Hall, C. M. (2009). Degrowing tourism: Decroissance, sustainable consumption and steadystate tourism. Anatolia, 20(1), 46-61. doi:10.1080/13032917.2009.10518894

Hall, C. M. (2010). Changing paradigms and global change: From sustainable to steady-state tourism. Tourism Recreation Research, 35(2), 131-143.

doi:10.1080/02508281.2010.11081629

Hart, C. (1998). Doing a literature review. London: Sage.

Harvey, D. (1990). The condition of postmodernity: An enquiry into the conditions of cultural change. Malden, MA: Blackwell.

Harvey, D. (2007). A brief history of neoliberalism. Oxford University Press

Hiernaux-Nicolas, D. (1999). Cancun Bliss. In D. Judd, \& S. Fainstein (Eds.), The Tourist City (pp.124-139) New Haven, CT, Yale University Press.

Horton, L. (2007). Grassroots struggles for sustainability in Central America. Boulder: University of Colorado Press.

Hughes, N. (2018). Tourists go home': Anti-tourism industry protest in Barcelona. Social Movement Studies, 1-7. doi: 10.1080/14742837.2018.1468244

Isaac, R. K., \& Platenkamp, V. (2010). Volunteer tourism in Palestine: A normative perspective. In O. Moufakkir, \& I. Kelly (Eds.), Tourism, progress and peace (pp. 148-161). Wallingford: CABI International.

Kallis, G. (2011). In defence of degrowth. Ecological Economics, 70(5), 873-880. doi:10.1016/j.ecolecon.2010.12.007

Kallis, G., Demaria, F., \& D’Alisa, G. (2014). Introduction: Degrowth. In G. D’Alisa, F. Demaria, \& G. Kallis (Eds.), Degrowth: A vocabulary for a new era. (pp. 1-17). New York, NY: Routledge.

Kallis, G., Kostakis, V., Lange, S., Muraca, B., Paulson, S., \& Schmelzer, M. (2018).

Research on Degrowth. Annual Review of Environment and Resources, 43(1), 291-226. doi:10.1146/annurev-environ-102017-025941

Koens, K., Postma, A., \& Papp, B. (2018). Is overtourism overused? Understanding the impact of tourism in a city context. Sustainability, 10(12), 4384. doi:10.3390/su10124384

Kousis, M. (2000). Tourism and the environment: A social movements perspective. Annals of Tourism Research, 27(2), 468-489. doi:10.1016/S0160-7383(99)00083-3

Koutra, C. (2010). Rapid situation analysis: A hybrid, multi-methods, qualitative, participatory approach to researching tourism development phenomena. Journal of Sustainable Tourism, 18(8), 1015-1033. doi:10.1080/09669582.2010.497221

Latouche, S. (2009). Farewell to growth. Cambridge: Polity.

Latouche, S. (2014). Imaginary, decolonization of. In G. D’Alisa, F. Demaria, \& G. Kallis (Eds.), Degrowth: A vocabulary for a new era (pp. 117-120). New York, NY: Routledge. 
Lew, A. A. (2017). Tourism planning and place making: Place-making or placemaking? Tourism Geographies, 19(3), 448-466. doi:10.1080/14616688.2017.1282007

Lew, A. A., \& Cheer, J. M. (Eds.). (2018). Tourism resilience and adaptation to environmental change. London: Routledge.

Lustosa, I. M. C., \& de Almeida, M. G. (2011). Turismo em terras indigenas: Auto-gest ao e novo colonialismo no nordeste do Brasil. [Tourism in indigenous territories: Self and new colonialism in Northeastern Brazil]. Revista Geografica de America Central, 2, 1-15.

Maney, G. M. (2001). Rival transnational networks and indigenous rights: The san blas kuna in Panama and the Yanomami in Brazil. Research in Social Movements, Conflicts and Change, 23, 103-144.

Mansilla, J. A. (2016). Urbanismo, privatizaci $\square$ on y marketing urbano. La Barcelona neoliberal a traves de tres ejemplos. [Urbanism, privatization and urban marketing. The neoliberal Barcelona through three exemptions]. Encrucijadas-Revista Critica de Ciencias Sociales, 11.

Mansilla, J. A. (2018). Vecinos en peligro de extincion. Turismo urbano, movimientos sociales y exclusion socioespacial en Barcelona. [Neighbors in danger of extinction. Urban tourism, social movements and socio-spatial exclusion in Barcelona]. PASOS Revista de Turismo y Patrimonio Cultural, 16(2), 279-296.

Mansilla, J. A., \& Milano, C. (2019). Becoming centre: Tourism placemaking and space production in two neighborhoods in Barcelona. Tourism Geographies, 1.

doi:10.1080/14616688.2019.1571097

McGehee, N. G. (2002). Alternative tourism and social movements. Annals of Tourism Research, 29(1), 124-143.

McGehee, N. G., \& Santos, C. (2005). Social change, discourse, and volunteer tourism. Annals of Tourism Research, 32(3), 760-779. doi:10.1016/j.annals.2004.12.002

Martınez-Alier, J., Pascual, U., Vivien, F. D., \& Zaccai, E. (2010). Sustainable de-growth: Mapping the context, criticisms and future prospects of an emergent paradigm. Ecological Economics, 69(9), 1741-1747. doi:10.1016/j.ecolecon.2010.04.017

Mayer, M. (2012). The "right to the city” in urban social movements. In N. Brenner, P. Marcuse, \& M. Mayer (Eds.), Cities for people, not for profit (pp. 63-85). New York, NY: Routledge.

Meadows, D., Meadows, D., Randers, J., \& Behrens, W. W. III, (1972). The limits to growth. A report for the Club of Rome's project on the predicament of mankind. New York, NY: Universe Books.

Medrano, H. F., \& Pardo, D. (2016). La lucha por el decrecimiento tur $\square$ 1stico: El caso de Barcelona. [The fight for tourist degrowth: The case of Barcelona]. Ecolog $\square$ 1a Pol $\square$ 1tica, (52), 104-106. 
Milano, C. (2017a). Turismofobia: Cuando el turismo entra en la agenda de los movimientos sociales. [Tourimophobia: When tourism enters the social movements agenda]. Marea Urbana, (1), 5-8.

Milano, C. (2017b). Overtourism and tourismphobia. Global trends and local contexts. Barcelona: Ostelea School of Tourism \& Hospitality.

Milano, C. (2018). Overtourism, malestar social y turismofobia. Un debate controvertido. [Overtourism, social unrest and tourismphobia. A controversial debate]. Pasos. Revista de Turismo y Patrimonio Cultural, 16(3), 551-564. doi:10.25145/j.pasos.2018.16.041

Milano, C., \& Mansilla, J. A. (2018). Ciudad de vacaciones. Conflictos urbanos en espacios turisticos. [City of vacations. Urban conflicts in tourist spaces]. Barcelona: PolLen Ediciones.

Milano, C., Cheer, J. M., \& Novelli, M. (2018). Overtourism: A growing global problem. Retrieved from https://theconversation.com/overtourism-a-growing-global-problem-100029

Milano, C., Cheer, J. M., \& Novelli, M. (2019). Overtourism: Excesses, discontents and measures in travel and tourism. Wallingford: CABI.

Milano, C., Novelli, M., \& Cheer, J. M. (2019). Overtourism and tourismphobia: A journey through four decades of tourism development, planning and local concerns. Tourism Planning \& Development, 16(4), 353-357.

Molotch, H. (1976). The city as a growth machine: Toward a political economy of place. American Journal of Sociology, 82(2), 309-332. doi:10.1086/226311

Novelli, M. (2015). Tourism and development in Sub-Saharan Africa: Current issues and local realities. London: Routledge.

Novelli, M., Morgan, N., Mitchell, G., \& Ivanov, K. (2016). Travel philanthropy and sustainable development: The case of the Plymouth Banjul challenge. Journal of Sustainable Tourism, 24 (6), 824-845. doi:10.1080/09669582.2015.1088858

O’Reilly, A. M. (1986). Tourism carrying capacity: Concept and issues. Tourism Management, 7(4), 254-258. doi:10.1016/0261-5177(86)90035-X

Owens, L. (2008). From tourists to anti-tourists to tourist attractions: The transformation of the Amsterdam squatters’ movement. Social Movement Studies, 7(1), 43-59. doi:10.1080/14742830801969340

Palou, S. (2011). Barcelona, destinacio turıstica. Promocio publica, turismes, imatges i ciutat (1888-2010). [Barcelona, tourist destination. Public promotion, tourisms, images and city (1888-2010)]. PhD Dissertation. University of Barcelona.

Lopoz-Palomeque, F. (2015). Barcelona, de ciudad con turismo a ciudad turistica: Notas sobre un proceso complejo e inacabado. [Barcelona, from a city with tourism to a tourist city: Notes on a complex and unfinished process]. Documents d'analisi geografica, 61(3), 04830506 .

Patton, M. Q. (2002). Qualitative research and evaluation methods. London: Sage. 
Robson, C. (2011). Real world research: A resource for users of social research methods in applied settings (3rd ed.). Chichester: Wiley.

Russo, A. P., \& Scarnato, A. (2018). "Barcelona in common”: A new urban regime for the 21st-century tourist city? Journal of Urban Affairs, 40(4), 455-474.

Schneider, F., Martinez-Alier, J., \& Kallis, G. (2011). Sustainable degrowth. Journal of Industrial Ecology, 15(5), 654-656. doi:10.1111/j.1530-9290.2011.00388.x

SET (2018). SET manifesto press release. Retrieved from

https://www.ecologistasenaccion.org/94342/ciudades-yregiones-del-sur-de-europa-contra-laturistizacion/

Smith, N. (1992). Geography, difference, and the politics of scale. In J. Doherty, E. Graham, \& M. Malek (Eds.) Postmodernism and the Social Sciences (pp. 57-79). London: Macmillan

Spencer, R. (2008). Lessons from Cuba: A volunteer army of ambassadors. In S. Wearing, \& K. Lyons (Eds.), Journeys of discovery in volunteer tourism: International case study perspectives. Oxfordshire: UK: CABI

Stephenson, M. L., \& Bianchi, R. (2014). Tourism and citizenship: Rights, freedoms and responsibilities in the global order. London: Routledge.

Sunol, X. (2016). Politiques publiques del turisme al segle XXI. [Public tourism policies in the 21st century]. In S. Palou Rubio (Eds.). Destinacio BCN. Historia del turismo a la ciutat de Barcelona. (pp.140-153). [Destination BCN. History of tourism in the city of Barcelona]. Barcelona: Efados; Arxiu Historic de la Ciutat.

Touraine, A. (1981). The voice and the eye: An analysis of social movements. Cambridge: Cambridge University Press.

Turner, L., \& Ash, J. (1975). The golden hordes: International tourism and the pleasure periphery. Constable Limited.

UN World Tourism Organization (2018). UNWTO Tourism Highlights, 2018. Madrid: Author.

UN World Tourism Organization (1983). Risks of saturation of tourist carrying capacity overload in holiday destinations. Madrid: Author.

Zald, M. N., \& McCarthy, J. D. (2017). Social movements in an organizational society: Collected essays. London: Routledge. 
